\title{
Distribution and habitat characteristics of dolphins of the genus Stenella (Cetacea: Delphinidae) in the southwest Atlantic Ocean
}

\author{
Ignacio B. Moreno ${ }^{1,2,7, *}$, Alexandre N. Zerbini ${ }^{3}$, Daniel Danilewicz ${ }^{1,2}$, \\ Marcos C. de Oliveira Santos ${ }^{4}$, Paulo C. Simões-Lopes ${ }^{5}$, Jose Lailson-Brito Jr. ${ }^{6}$, \\ Alexandre F. Azevedo ${ }^{6}$ \\ ${ }^{1}$ Grupo de Estudos de Mamíferos Aquáticos do Rio Grande do Sul (GEMARS), Rua Felipe Neri 382/203, Porto Alegre, \\ Rio Grande do Sul 90440-150, Brazil \\ ${ }^{2}$ Centro de Estudos Costeiros, Limnológicos e Marinhos (CECLIMAR) \& Universidade Federal do Rio Grande do Sul \\ (UFRGS), Avenida Tramandaí 976, Imbé, Rio Grande do Sul 95625-000, Brazil \\ ${ }^{3}$ Washington Cooperative Fish and Wildlife Research Unit, School of Aquatic and Fishery Sciences, Box 355020, \\ University of Washington, Seattle, Washington 98195-5020, USA \\ ${ }^{4}$ Projeto Atlantis - Departamento de Ecologia Geral, Instituto de Biociências — USP, Rua do Matão 321 , \\ Cidade Universitária, São Paulo, São Paulo 05508-900, Brazil \\ ${ }^{5}$ Laboratório de Mamíferos Aquáticos, Departamento de Ecologia e Zoologia, Universidade Federal de Santa Catarina, \\ Caixa Postal 5102, Florianópolis, Santa Catarina 88040-970, Brazil \\ ${ }^{6}$ Laboratório de Mamíferos Aquáticos (MAQUA)/UERJ, Rua São Francisco Xavier 524/4018E, Rio de Janeiro, \\ Rio de Janeiro 20550-013, Brazil
}

${ }^{7}$ Present address: Pós-Graduação em Biociências, Laboratório de Ictiologia, Museu de Ciências e Tecnologia/PUCRS, Avenida Ipiranga 6681, Caixa Postal 1429, Porto Alegre, Rio Grande do Sul 90619-900, Brazil

\begin{abstract}
The distribution of dolphins of the genus Stenella is poorly known in the southwest Atlantic Ocean. A complete review of records $(n=311)$ of these dolphin species was performed to describe distribution and habitat. Atlantic spotted dolphins $S$. frontalis occur in both southern (21 to $33^{\circ} \mathrm{S}$ ) and northern Brazil (north of $06^{\circ} \mathrm{S}$ ), with a hiatus in its distribution off eastern South America. This species presents the highest preference for nearshore habitats, restricted to waters within the $1000 \mathrm{~m}$ isobath. Pantropical spotted dolphins $S$. attenuata are found in tropical waters as far south as $22^{\circ} \mathrm{S}$ and are mainly observed off northeastern South America. They occur beyond the continental shelf break in depths $>850 \mathrm{~m}$. Clymene dolphins $S$. clymene are distributed in deep waters (1390 to $4500 \mathrm{~m}$ ) as far south as $30^{\circ} \mathrm{S}$. Strandings are more common where the continental shelf is narrower. Spinner dolphins $S$. longirostris are found in oceanic waters as far south as $30^{\circ} \mathrm{S}$. They inhabit tropical waters over the shelf and slope (depths ranging from 170 to $2700 \mathrm{~m}$ ). The striped dolphin $S$. coeruleoalba is the least known species of the genus in the western South Atlantic. Most records are from temperate waters in southern Brazil and Argentina. The distributions of $S$. attenuata, $S$. clymene and $S$. longirostris overlap to a great extent and are predominantly oceanic and associated with warm ocean currents. $S$. frontalis seems to prefer a different, coastal habitat, influenced both by warm currents and upwelling areas. The discontinuous distribution of this species suggests that an isolated population inhabits the southern coast of Brazil.
\end{abstract}

KEY WORDS: Stenella · Atlantic Ocean · Brazil · Uruguay · Argentina · Distribution · Habitat characteristics 


\section{INTRODUCTION}

The genus Stenella Gray, 1866, comprises 5 species of dolphins distributed worldwide in tropical, subtropical and temperate oceans. Two species are endemic to the Atlantic Ocean, Gulf of Mexico and the Caribbean: the Atlantic spotted dolphin Stenella frontalis (Cuvier, 1829) and the Clymene dolphin S. clymene (Gray, 1850) (Perrin 2001a, Fertl et al. 2003). The other 3 species, the pantropical spotted dolphin $S$. attenuata (Gray, 1846), the spinner dolphin S. longirostris (Gray, 1828), and the striped dolphin S. coeruleoalba (Meyen, 1833) inhabit all major ocean basins (Archer \& Perrin 1999, Perrin 2001b,c).

The taxonomy of some species of Stenella remained uncertain until the 1980s, when the Clymene dolphin was rediscovered (Perrin et al. 1981) and the spotted dolphins were revised (Perrin et al. 1987). Although the 5 species are currently well characterized, the genus is considered an artificial and non-monophyletic assemblage (LeDuc et al. 1999, Perrin 2001a). Due to previous taxonomic uncertainties, caused by the similarity of external color pattern among some species and the overlap in the ranges of several osteological features, many records of Stenella have remained unidentified or, in some cases, have been misidentified. For example, the pantropical spotted dolphin has been confused at sea with the Atlantic spotted dolphin (e.g. Würsig et al. 2000, Perrin 2001b), and the Clymene dolphin has often been confused with spinner and common dolphins (Delphinus spp.) (e.g. Fertl et al. 2003).

The distribution and abundance of dolphins of the genus Stenella are well known in the North Pacific Ocean and in the Gulf of Mexico (Reilly \& Fiedler 1993, Wade \& Gerrodette 1993, Davis et al. 1998, 2002). In contrast, the occurrence and habitat of Stenella species remain relatively poorly known in other major ocean basins (e.g. Perrin \& Hohn 1994). One example is the southwest Atlantic Ocean (SWA), where records of the 5 species have been observed (Brownell \& Praderi 1976, Perrin et al. 1981, Praderi 1991a, Ximenez \& Praderi 1992, Simões-Lopes et al. 1994, Secchi \& Siciliano 1995, Ott \& Danilewicz 1996, Zerbini \& Kotas 1998, Zerbini et al. 2004a), but a thorough description of the distribution patterns of most of them has not been undertaken. The only exception is the Clymene dolphin, whose distribution has been recently reviewed, including new data from the eastern coast of South America
(Fertl et al. 2003). In the current paper new information on the occurrence of Stenella dolphins is presented and published records are reviewed in order to provide a comprehensive description of the distribution patterns and habitat preferences of these species in the SWA.

\section{METHODS}

Study area. The SWA is defined here as waters south of the equator and west of $20^{\circ} \mathrm{W}$. The SWA is under the influence of 3 different major water masses/currents. The South Equatorial Current runs west in the equatorial Atlantic towards the northern coast of South America, where it splits into 2 currents. The North Brazil Current runs northwest parallel to the northern coast of South America towards the Amazon basin and the Caribbean, and the Brazil Current flows southward along the eastern coast of South America (Peterson \& Stramma 1990). A third water mass, the Malvinas Current, flows northward from the southern tip of the South American continent along the coast of Argentina, Uruguay and southern/southeastern Brazil (Fig. 1).

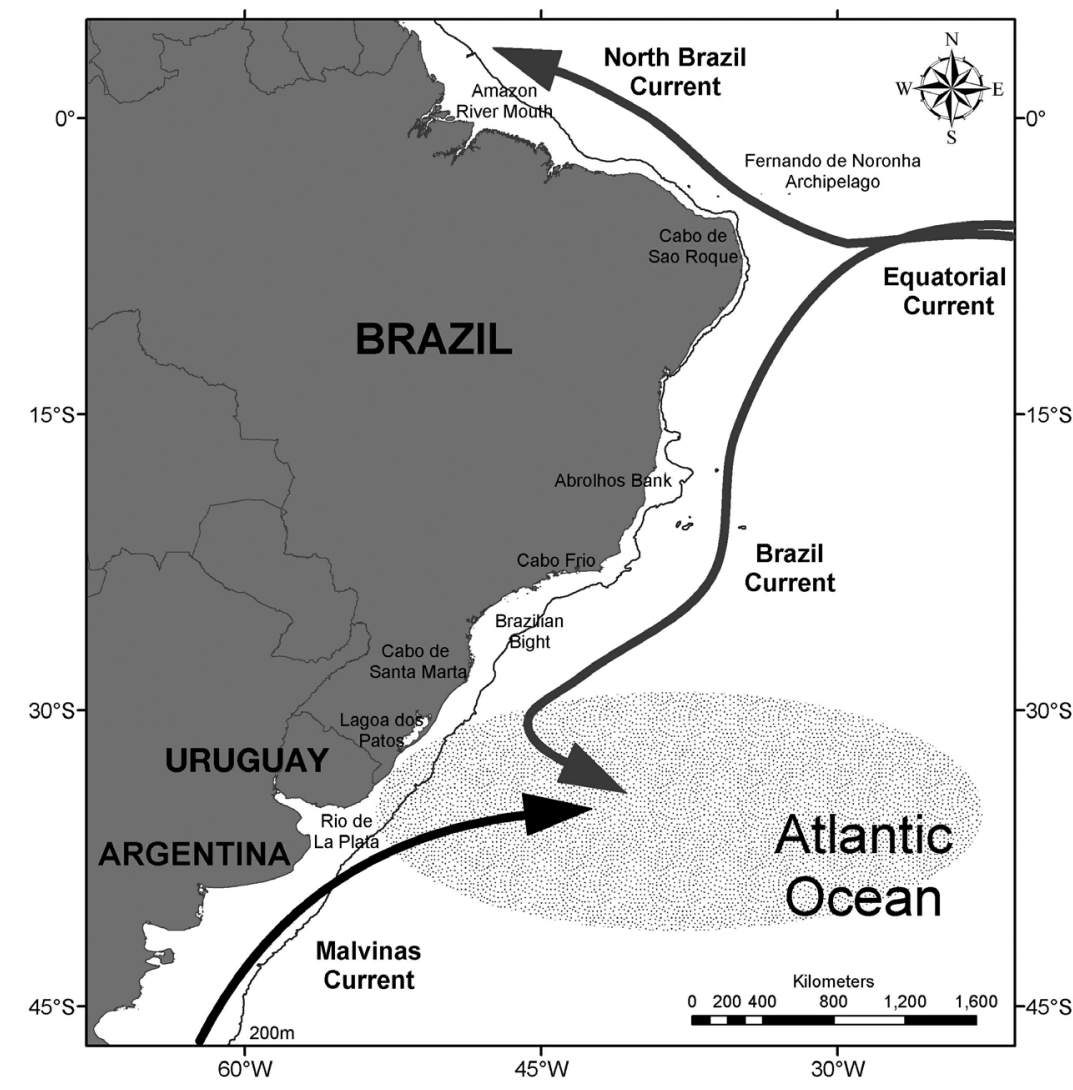

Fig. 1. Oceanic-scale currents and oceanographic and bathymetric features in the western south Atlantic Ocean. The shaded oval approximately corresponds to the Subtropical Convergence 
The SWA is under the influence of the Brazil Current up to about 30 to $40^{\circ} \mathrm{S}$ (see Garzoli 1993). This oligotrophic current is characterized by relatively high seasurface temperature (SST, 22 to $30^{\circ} \mathrm{C}$ ) and salinity (34 to $36 \%$ ) (Seeliger et al. 1997). The coasts of Argentina, Uruguay and southern Brazil are influenced by the Malvinas Current, with lower temperature (SST, 14 to $18^{\circ} \mathrm{C}$ ) and salinity (33\%). The Brazil and Malvinas Currents converge between approximately 30 and $40^{\circ} \mathrm{S}$ (Boltovskoy 1981) and are forced offshore, forming the Subtropical Convergence (Castello \& Möller 1977). The latitude at which the currents converge varies seasonally, with a northward penetration of the Malvinas Current during austral winter and a southward shift of the Brazil Current during austral summer (Legeckis \& Gordon 1982). The waters in this region receive a large amount of continental freshwater input from the La Plata River (ca. $35^{\circ} 30^{\prime} \mathrm{S}, 056^{\circ} \mathrm{W}$ ) and the Lagoa dos Patos (ca. $32^{\circ} \mathrm{S}, 052^{\circ} \mathrm{W}$ ). The Subtropical Convergence (Fig. 1) has an important influence on the ecosystem of a large portion of the continental shelf and the slope between Cabo de Santa Marta Grande, Brazil $\left(28^{\circ} 40^{\prime} \mathrm{S}\right)$, and Uruguay $\left(34^{\circ} 40^{\prime} \mathrm{S}\right.$ ) (Seeliger et al. 1997).

The region known as the Brazilian Bight (Fig. 1) extends from Cabo Frio $\left(23^{\circ} \mathrm{S}\right)$ to Cabo de Santa Marta $\left(28^{\circ} \mathrm{S}\right)$. This area is strongly influenced by upwelling and presents complex and dynamic hydrographic variation. The interaction between eddy-induced upwelling and wind-generated Ekman transport results in enhanced bottom intrusion of the South Atlantic central water onto the shelf break (Valentini \& Cardoso 1991). This seasonal wind-driven upwelling of cold, nutrient-rich waters is observed in the region between Cabo Frio and São Sebastião $\left(24^{\circ} \mathrm{S}\right)$ over a great extent of the continental shelf and increases biological productivity (Borzone et al. 1999). For example, the main Brazilian fishery resource, the Brazilian sardinella Sardinella brasiliensis, presents the highest biomass levels in this area (Valentini \& Cardoso 1991).

Ocean bathymetric features vary along the eastern coast of South America. At the northeastern portion of the South American continent, the continental shelf is oriented along a north-south axis. From Cabo de São Roque $\left(5^{\circ} \mathrm{S}\right)$ to about $16^{\circ} \mathrm{S}$ the shelf is narrow (20 to $50 \mathrm{~km}$ wide) and the slope is relatively steep. A widening of the shelf occurs between 16 and $20^{\circ} \mathrm{S}$. This broader shelf corresponds to the Abrolhos Banks, which are predominantly formed by coral reefs. In this area the $200 \mathrm{~m}$ isobath is located up to $250 \mathrm{~km}$ from the shore (Floeter et al. 2001). South of the Abrolhos Bank the shelf becomes narrower again until Cabo Frio $\left(22^{\circ} \mathrm{S}\right)$, where the orientation of the coast changes to a northeast-southwest axis and a new widening of the shelf occurs. This new broadening of the continental shelf corresponds to the Brazilian Bight (20 to $\left.29^{\circ} \mathrm{S}\right)$. At Cabo de Santa Marta $\left(29^{\circ} \mathrm{S}\right)$, the continental shelf break is located close to shore. However, from this location, the shelf becomes wide again towards the southern end of the South American continent, where it reaches its broadest point in the SWA.

Data collection. In this study, both published and unpublished strandings, incidental catches and sightings were reviewed. Stranded and incidentally captured animals have been recorded by various research groups along the coast of South America (Praderi 1991a, Simões-Lopes \& Ximenez 1993, Ott \& Danilewicz 1996, Lucena et al. 1998, Bastida et al. 2001, Rosas et al. 2002, Di Beneditto 2003).

Sighting data were collected during opportunistic and dedicated ship surveys. Opportunistic sightings were recorded by both experienced and nonexperienced marine mammal observers on board fishing or research vessels. Dedicated, systematic surveys were conducted in 2 major areas. Oceanographic cruises of the Project REVIZEE, SCORE Sul (Assessment of the Living Resources of the Brazilian Economic Exclusive Zone) (e.g. Zerbini et al. 2004a) covered the outer continental shelf and slope (depths of 100 to $1800 \mathrm{~m}$ ) off the southern and southeastern coast of Brazil, between Cabo de São Tome $\left(22^{\circ} \mathrm{S}\right)$ and Chui $\left(33^{\circ} 45^{\prime} \mathrm{S}\right)$. Cruises took place in winter (July/August 1996), autumn (April/May 1997) and spring (November/December 1997). Line transect ship surveys for cetacean abundance estimation were carried out off the northeastern coast of Brazil. Four cruises were conducted from 3 to $12^{\circ} \mathrm{S}$ and from the $20 \mathrm{~m}$ isobath to the $033^{\circ} \mathrm{W}$ meridian (depths of ca. 4000 to $4500 \mathrm{~m}$ ) in the winter or spring of 1998, 1999, 2000 and 2001 (e.g. Zerbini et al. 2004b).

When a group of dolphins was sighted, the following information was collected: date, time observed, position with GPS (Global Positioning System), water depth using a depth sounder when available (or in retrospect by plotting sightings on bathymetric charts), individuals to the lowest possible taxon, estimated number of individuals, presence of calves, behavioral observations, and film and frame numbers of photographs taken. Environmental variables such as cloud cover, wind strength and direction, sea state (Beaufort scale) and sea-surface temperature were also recorded, when possible, during the surveys.

Group sizes were estimated by a range of different observers, most of them $(75 \%)$ with experience in cetacean observation. Dolphin counting was usually limited to the dolphins that approached the vessel (e.g. bow-ride). This procedure may lead to more imprecise group size estimates than aerial estimates (Scott et al. 1985); nevertheless, observer estimates from boats, although often unsatisfactory for large aggregations, 
must often be relied upon for school size data (Scott et al. 1985).

Only records that could be unequivocally identified to species level were included in this study. Scientific collections of several institutions (Appendix 1, www.int-res.com/articles/suppl/appendix_moreno.pdf) were visited by the senior author to examine osteological material collected from stranded or incidentally captured individuals. Dolphins were identified by skull morphology and metrics, as described by Perrin (1975), Perrin et al. (1981, 1987) and Moreno (2002). If osteological material was not available, individuals were identified according to their color patterns (Perrin 1975, 1981, 1987, Jefferson et al. 1993, Archer \& Perrin 1999). Only sightings obtained by experienced marine mammal researchers or those that presented features that allowed indisputable species identification (e.g. good quality photographs) were considered in this study. All sighting records were examined by at least 1 , but usually more than 2 of the authors to confirm the species identification.

\section{RESULTS}

A total of 311 records of Stenella were reviewed (Appendix 2, www.int-res.com/articles/suppl/appendix_moreno.pdf) and 295 were identified to species level: 165 strandings, 113 sightings and 17 incidentally caught (Table 1). Records and proposed distribution patterns of all species are presented in Figs. 2 to 6 . In the SWA the distribution of $S$. attenuata, S. clymene and $S$. longirostris are oceanic and overlap to a great extent, while $S$. frontalis seems to prefer a different, more shallow habitat (Fig. 7, Table 2).

\section{Atlantic spotted dolphin}

Records of Atlantic spotted dolphins ( $\mathrm{n}=153$ ) occurred in 2 different regions, north of $6^{\circ} \mathrm{S}$ and between 21 and $33^{\circ} \mathrm{S}$, indicating a discontinuous distribution along the eastern coast of the South American conti-

Table 1. Stenella spp. Summary of records in the southwest Atlantic Ocean

\begin{tabular}{|lcccr|}
\hline Species & Strandings & Sightings & Captures & Total \\
\hline S. frontalis & 98 & 43 & 12 & 153 \\
S. attenuata & 9 & 45 & 0 & 54 \\
S. longirostris & 10 & 10 & 2 & 22 \\
S. clymene & 29 & 13 & 0 & 42 \\
S. coeruleoalba & 19 & 2 & 3 & 24 \\
& $\mathbf{1 6 5}$ & $\mathbf{1 1 3}$ & $\mathbf{1 7}$ & $\mathbf{2 9 5}$ \\
\hline
\end{tabular}

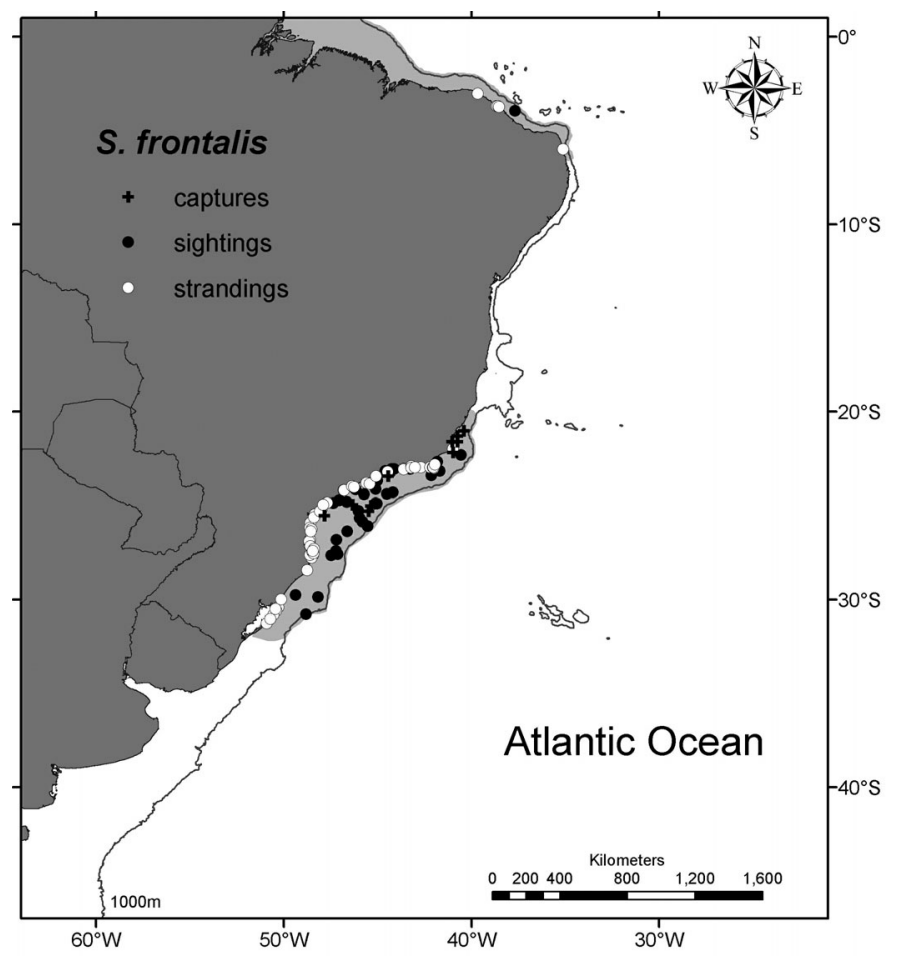

Fig. 2. Stenella frontalis. Records and proposed distribution (shaded area) in the southwest Atlantic Ocean

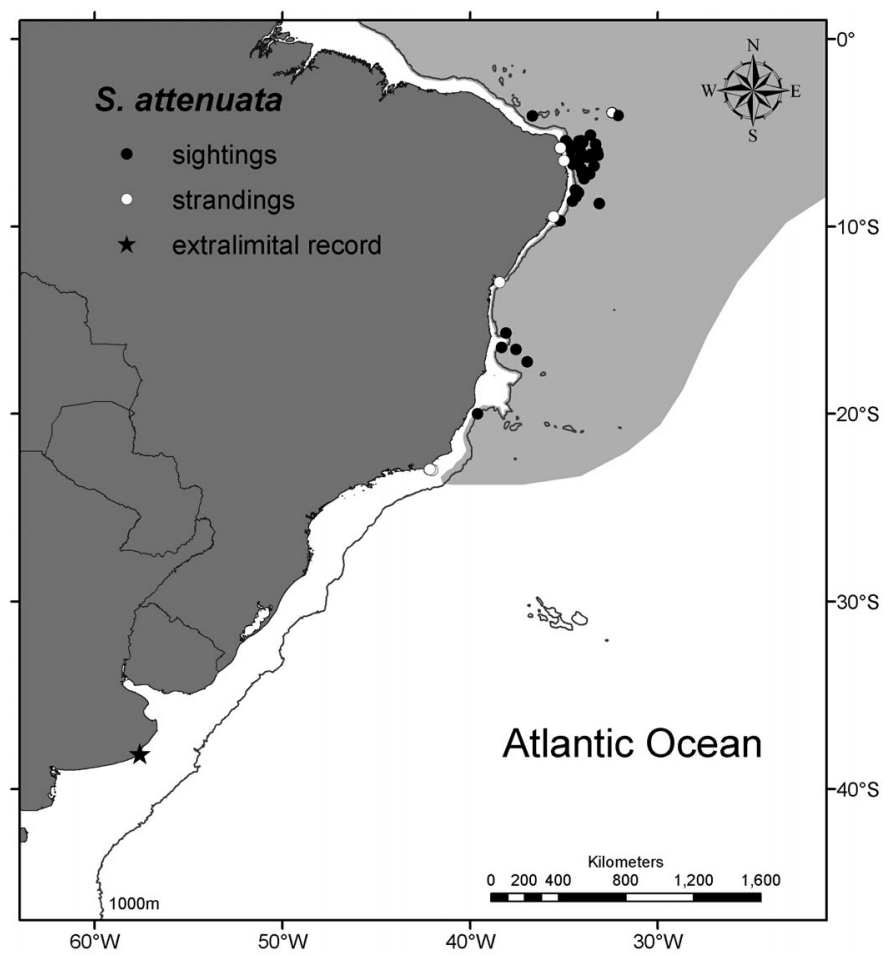

Fig. 3. Stenella attenuata. Records and proposed distribution (shaded area) in the southwest Atlantic Ocean (offshore limits are poorly known and are tentatively represented here) 


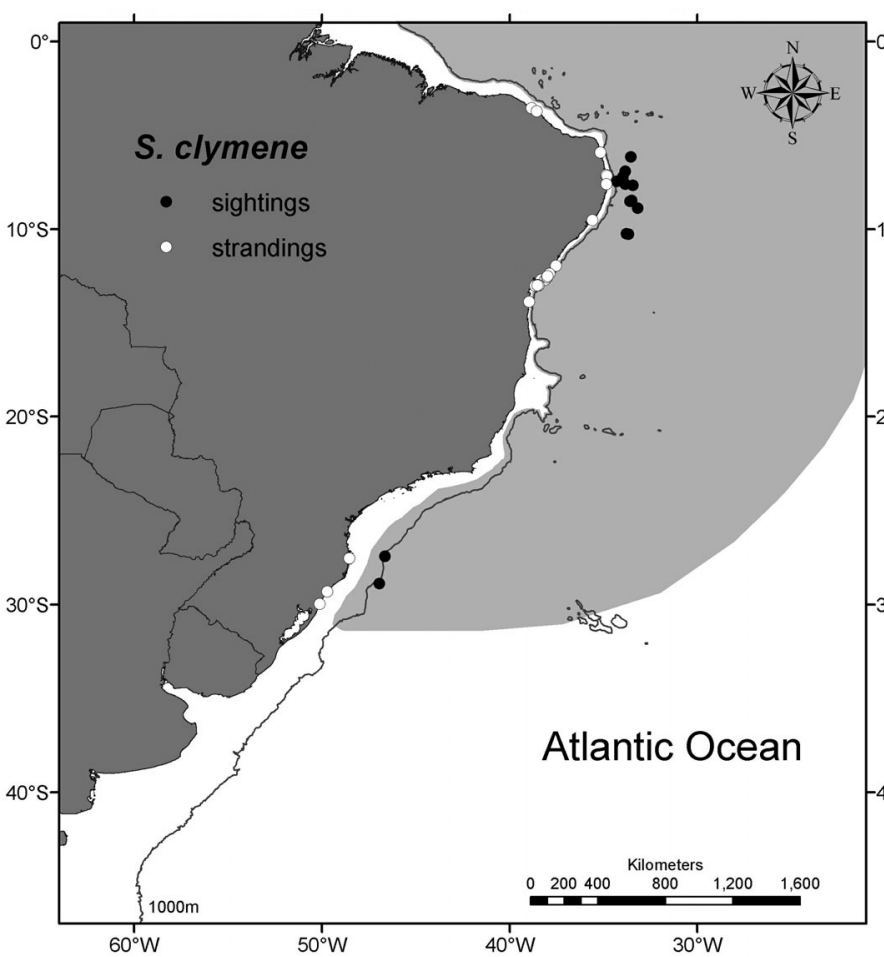

Fig. 4. Stenella clymene. Records and proposed distribution (shaded area) in the southwest Atlantic Ocean (offshore limits are poorly known and are tentatively represented here)

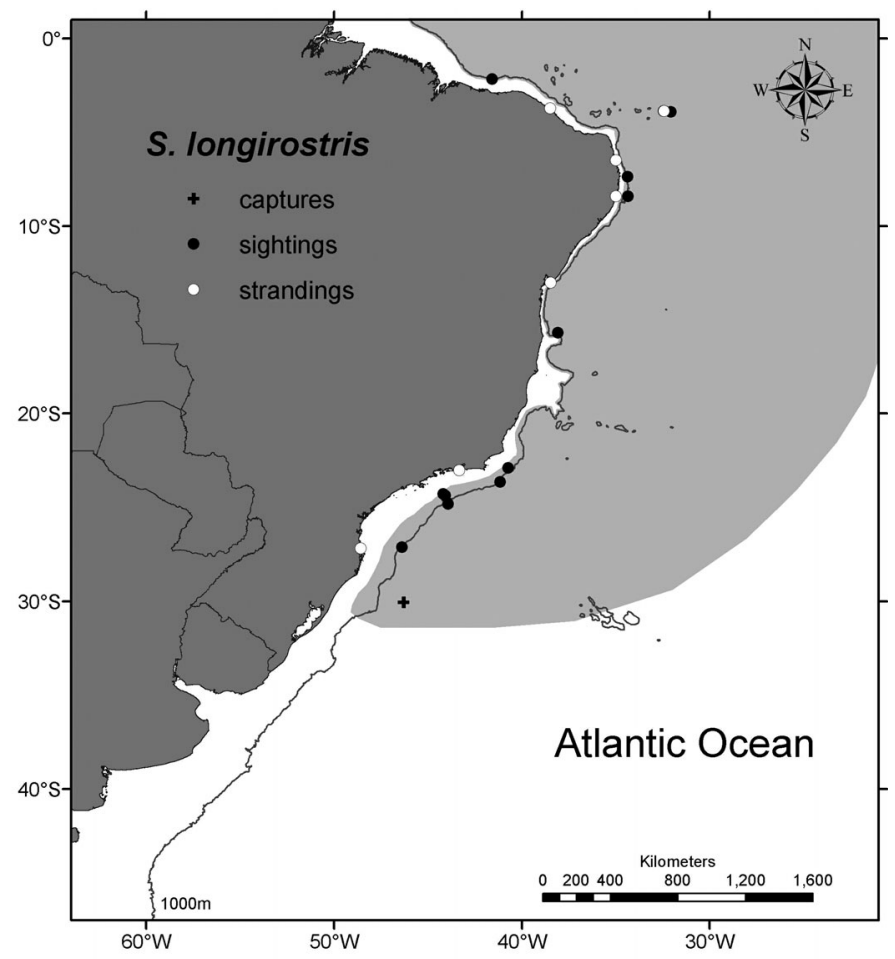

Fig. 5. Stenella longirostris. Records and proposed distribution (shaded area) in the southwest Atlantic Ocean (offshore limits are poorly known and are tentatively represented here)

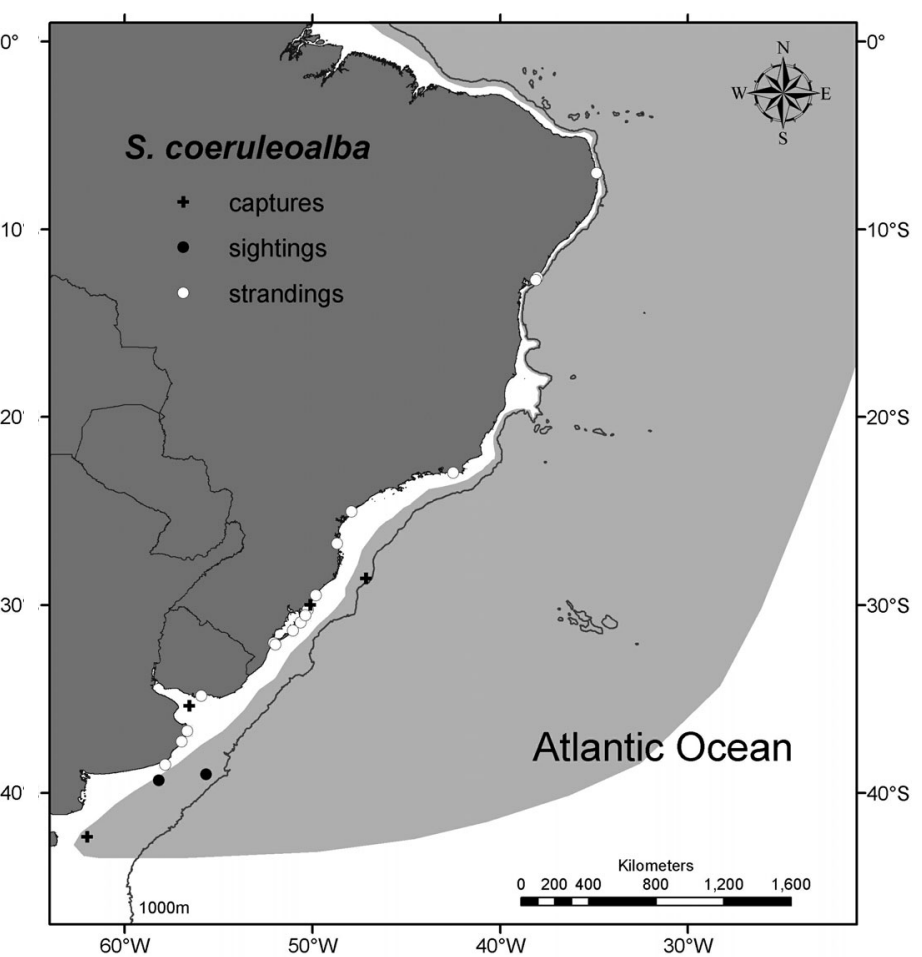

Fig. 6. Stenella coeruleoalba Records and proposed distribution (shaded area) in the southwest Atlantic Ocean (offshore limits are poorly known and are tentatively represented here)

nent (Fig. 2). This was the only species of the genus to regularly inhabit nearshore shallow areas, although sightings were also reported in deeper waters. Dolphins were sighted in depths ranging from the upper continental shelf $(20 \mathrm{~m})$ to the slope area $(961 \mathrm{~m})$. SST ranged from 19 to $27^{\circ} \mathrm{C}$ (Table 2). Group sizes were relatively small when compared to those for the other Stenella species, with almost $90 \%$ of them being smaller than 50 (range $=2$ to 200 individuals) (Fig. 8).

\section{Pantropical spotted dolphin}

Pantropical spotted dolphin records $(n=54)$ were observed as far south as $22^{\circ} \mathrm{S}$. This species showed a preference for deep waters, usually beyond the continental shelf break (Fig. 3). Sightings were recorded over depths ranging from 850 to $4900 \mathrm{~m}$ and in areas where the SST varied from 26 to $28^{\circ} \mathrm{C}$ (Table 2). Group size ranged from 3 to 250 dolphins (Fig. 8). Most sightings were recorded along the northeastern coast of Brazil, but a few were observed farther south. Sightings around oceanic islands (e.g. Fernando de Noronha Archipelago-0351' S, $032^{\circ} 25^{\prime} \mathrm{W}$ ) have also been reported (Liliane Lodi [Rio de Janeiro, 2001] pers. comm., José Martins da Silva Jr. [Fernando de Naronha, 2005] pers. comm.). 


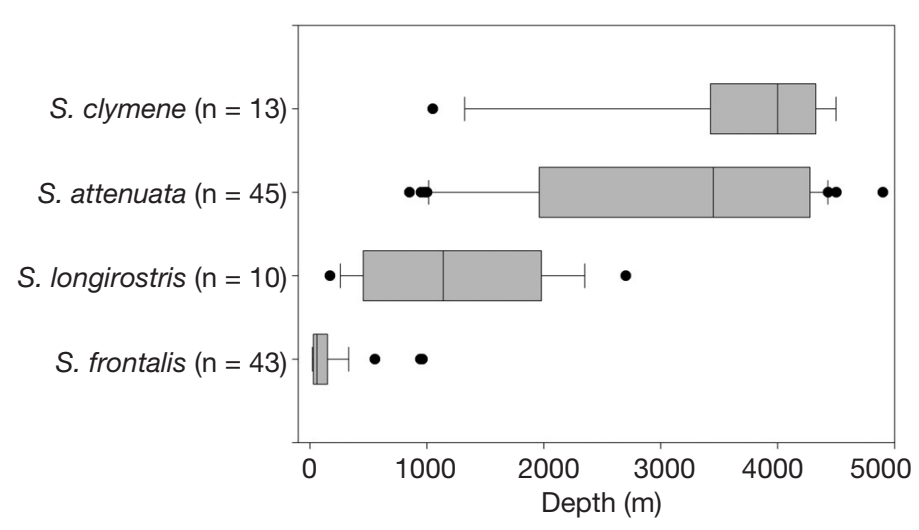

Fig. 7. Stenella spp. Box plot of depth distribution of sightings of 4 species in the southwest Atlantic Ocean. The thick vertical line inside each box represents the median; lateral borders of the box are the 25th and 75th percentiles; the 5th and 95th percentiles are represented by the error bars; $\bullet$ : outliers

\section{Clymene dolphin}

A total of 42 occurrences of Clymene dolphins were recorded, from the northern coast of Brazil (ca. $3^{\circ} \mathrm{S}$ ) to as far south as $29^{\circ} 59^{\prime} \mathrm{S}, 050^{\circ} 07^{\prime} \mathrm{W}$ (Fig. 4). Sightings were recorded between the 1050 and $4500 \mathrm{~m}$ isobaths (Table 2). As for pantropical spotted dolphins, most sightings were observed off the northeastern portion of the South American continent. SST ranged from 25 to $28.5^{\circ} \mathrm{C}$ (Table 2). Groups ranged from 8 to 300 individuals (Fig. 8). Strandings are very common along the northeastern coast of Brazil, where about $89 \%(n=26)$ of the records occurred, but few were reported farther south $(n=3)$ in southern Brazil. No records of Clymene dolphins were observed in Uruguay or Argentina.

\section{Spinner dolphin}

Spinner dolphins were found in tropical oceanic waters off the eastern coast of South America as far south as $30^{\circ} \mathrm{S}$ (Fig. 5). This species is seen year round near the Fernando de Noronha Archipelago $\left(03^{\circ} 51^{\prime} \mathrm{S}\right.$,

Table 2. Stenella spp. Water depth and sea-surface temperature at sighting locations in the southwest Atlantic Ocean

\begin{tabular}{|lrrcrrr|}
\hline \multirow{2}{*}{ Species } & $\mathrm{n}$ & \multicolumn{3}{c}{ Water depth $(\mathrm{m})$} & \multicolumn{3}{c|}{$\begin{array}{c}\text { Sea-surface temperature }\left({ }^{\circ} \mathrm{C}\right) \\
\text { Median }\end{array}$} & Range & $\mathrm{n}$ & Median & Range \\
\hline S. frontalis & 43 & 60 & $20-961$ & 33 & 22.6 & $19.0-27.0$ \\
S. attenuata & 45 & 3450 & $850-4900$ & 38 & 26.7 & $26.0-28.0$ \\
S. longirostris & 10 & 1140 & $170-2700$ & 7 & 23.8 & $22.0-27.5$ \\
S. clymene & 13 & 4000 & $1050-4500$ & 12 & 26.3 & $20.2-28.5$ \\
\hline
\end{tabular}

$032^{\circ} 25^{\prime} \mathrm{W}$ ), where a local population exists (Silva et al. 2005). Apart from this locality, sightings $(n=10)$ were made in tropical regions on the outer continental shelf and beyond the continental slope in waters from 170 to $2700 \mathrm{~m}$ deep. Average SST ranged from 22 to $27.5^{\circ} \mathrm{C}$ (Table 2). Only 8 sightings had their group size estimated and they ranged from 5 to 250 individuals (Fig. 8). Few strandings were observed $(n=10)$, although this species is common along the northern Brazilian coast. Only 2 incidental captures were recorded, 1 between São Paulo and Rio de Janeiro States and the other off Rio Grande do Sul State, in southern Brazil.

\section{Striped dolphin}

The striped dolphin was the only species observed in both temperate and tropical regions in the SWA (Fig. 6). Most of the sightings and incidental captures were recorded in relatively shallow waters (ranging from 30 to $100 \mathrm{~m}$ ) in southern Brazil and Argentina (Pinedo \& Castello 1980, Bastida et al. 2001, present study). Sightings of small groups (1 to 4 individuals) were recorded only in cold waters off Argentina (Bastida et al. 2001). This was the only species of the genus Stenella with reliable contemporary records in Argentina. Strandings are also more frequent between 30 and $38^{\circ} \mathrm{S}$. However, there were 3 records in southeastern Brazil from ca. $23^{\circ} \mathrm{S}$ to $28^{\circ} 30^{\prime} \mathrm{S}$ and 3 further north along the northeastern Brazilian coast (Lucena et al. 1998, Maia-Nogueira et al. 2001, Rosas et al. 2002, present study) (Fig. 6).

\section{DISCUSSION}

\section{Atlantic spotted dolphin}

The Atlantic spotted dolphin occurred over the continental shelf and slope up to $1000 \mathrm{~m}$ of depth. This distribution pattern is similar to the one observed along the southeastern coast of the United States and the Gulf of Mexico, where Stenella frontalis occurs over the continental shelf in depths ranging from 20 to $200 \mathrm{~m}$, with a few scattered records up to $1000 \mathrm{~m}$ (Jefferson \& Schiro 1997, Würsig et al. 2000). The southern range of $S$. frontalis corresponds to the region influenced by the Subtropical Convergence in southern Brazil. In Rio Grande do Sul (30 to $\left.34^{\circ} \mathrm{S}\right)$, southern Brazil, strandings of this species were primarily recorded in warmer months (January [n = 2], May [n=1], October [n = 1] and November $[n=3]$ ) when the area is 


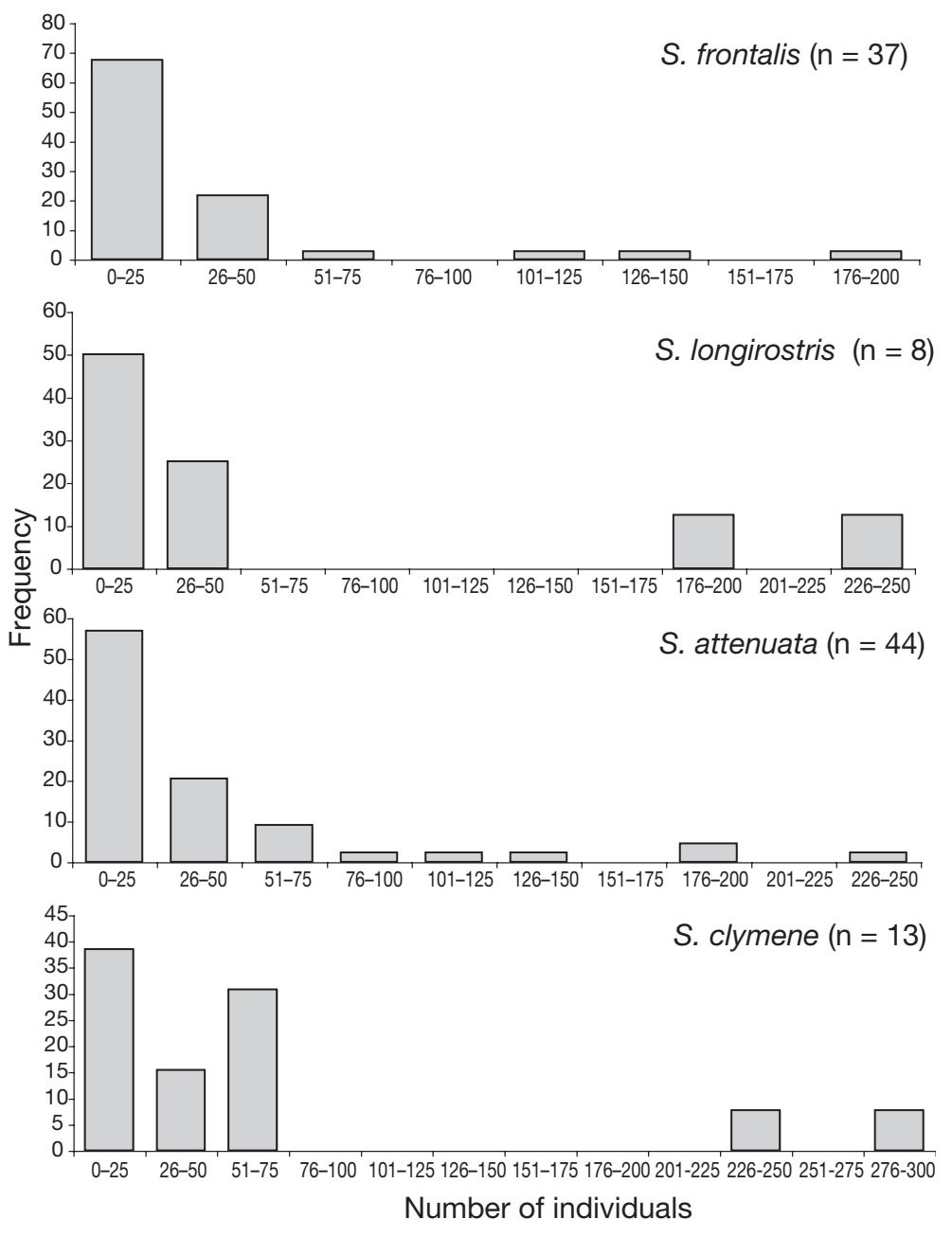

Fig. 8. Stenella spp. Distribution of estimated group size for 4 species in the southwest Atlantic Ocean

under influence of the warm Brazil Current. SST averages $22^{\circ} \mathrm{C}$ in this period and is about $6^{\circ} \mathrm{C}$ higher than in colder months (mean of $16^{\circ} \mathrm{C}$ from June to August) (Danilewicz 2003). This suggests that the species prefers tropical waters and may avoid the southern coast of Brazil when the SST is under the influence of the Malvinas Current.

The distribution of Stenella frontalis in the western Atlantic Ocean has been described as continuous, from the central coast of North America (ca. $50^{\circ} \mathrm{N}$ ), through the Caribbean and along the northern and eastern coast of South America, down to about 25 to $30^{\circ} \mathrm{S}$ (e.g. Perrin et al. 1987, Jefferson et al. 1993, Rice 1998, Perrin 2001a). However, the results presented here show an absence of records of this species along the coast of Brazil between 6 and $21^{\circ} \mathrm{S}$, strongly indicating a discontinuous distribution in the SWA. In recent years, monitoring for stranded and incidentally killed specimens has substantially increased along the southern, southeastern and northeastern coasts of Brazil, but no records of Atlantic spotted dolphins have been reported between 6 and $21^{\circ} \mathrm{S}$. In addition, ship and aerial surveys conducted between the Cape of São Roque $\left(\sim 5^{\circ} \mathrm{S}\right)$ and the southern portion of the Abrolhos Bank $\left(19^{\circ} \mathrm{S}\right)$ have not reported $S$. frontalis sightings (e.g. Andriolo et al. 2003, Cristiane Martins [Bahia, 2003] pers. comm., present study). Other cetacean species, such as bottlenose dolphins Tursiops truncatus, marine tucuxis Sotalia fluviatilis and roughtoothed dolphins Steno bredanensis, which are common in coastal waters, were observed in these surveys. On the other hand, $S$. frontalis seems to be abundant off southeastern and southern Brazil. Zerbini et al. (2004a) reported that this was the most commonly sighted species during oceanographic surveys in these regions.

The Atlantic spotted dolphin feeds on a wide variety of prey, including benthic and pelagic fishes, cephalopods and benthic invertebrates, that occur over the continental shelf and slope (Perrin et al. 1987). The lack of records of Stennella frontalis between 6 and $21^{\circ} \mathrm{S}$ could be attributed to different factors, such as absence of prey, low productivity of the region, competition with other coastal species, historical zoogeographic process and other influences. The continental shelf along the South American coast is remarkably narrow from 6 to $16^{\circ} \mathrm{S}$ and the local productivity is low, with a total estimated fish biomass $77 \%$ lower than the estimated biomass of the shelf located between 20 and $34^{\circ} \mathrm{S}$ (Paiva 1997). The continental shelf broadens between 16 and $20^{\circ} \mathrm{S}$ and forms the Abrolhos Bank, the largest coral reef area in the SWA. Yet, local productivity is low and some of the typical prey (e.g. cephalopods) of $S$. frontalis seem not to be either present or abundant in the area. This region is poorer in reef-fish species than rocky areas further to the south. Floeter et al. (2001) attributed the low diversity in the Abrolhos Bank to São Francisco and Doce River freshwater and sediment barriers.

The stock structure of Stenella frontalis is poorly known. The hiatus in the distribution in the SWA indicates potential for the existence of at least 2 distinct populations. Dolphins distributed off the northern coast of South America (north of $6^{\circ} \mathrm{S}$ ) may represent the southern range of a population that is connected to the Caribbean, Gulf of Mexico and North Atlantic Ocean, where the species is known to occur (e.g. Perrin et al. 1987, Jefferson et al. 1993, Romero et al. 2001). Atlantic spotted dolphins were not observed north of about $3^{\circ} \mathrm{S}$ or west of $40^{\circ} \mathrm{W}$ along the northern 
coast of South America. The absence of records is probably a consequence of the notable lack of observation effort in the area. The species is seen further west off the coast of Venezuela and in the Caribbean (e.g. Romero et al. 2001). However, further studies need to be conducted to verify if the Atlantic spotted dolphin is continuously distributed off northern South America.

A second, geographically and possibly reproductively isolated, population is found in southern and southeastern Brazil (21 to $33^{\circ} \mathrm{S}$ ). Moreno (2002) compared the skull morphology and morphometrics of specimens from this area with those from the North Atlantic Ocean and Caribbean and found significant differences in shape, metric and meristic characters. Reproductive isolation may make this population more vulnerable to human impacts. Currently, the main source of human-induced mortality in the southern range of the species is bycatch in fishing gear, particularly bottom set and drift gillnets (e.g. Zerbini \& Kotas 1998, Di Beneditto 2003). Other harmful anthropogenic activities, such as coastal development, oil and gas exploration and fisheries, may cause habitat degradation, underwater noise and overfishing of prey species. Therefore, due to its unknown status, possible isolation and relatively limited range, further studies on abundance and trends, mortality and genetic structure should be viewed as a priority to assess the conservation status of this Atlantic spotted dolphin population.

\section{Pantropical spotted dolphin}

The pantropical spotted dolphin is found in tropical, subtropical and warm-temperate oceans around the world (Perrin \& Hohn 1994, Perrin 2001b). In the eastern tropical Pacific Ocean 2 different sub-species are recognized, one distributed in offshore waters (Stenella a. attenuata) and the other restricted to shallow waters within $200 \mathrm{~km}$ off the coast (S. a. graffmani) (Perrin 1975, 2001b). In the Gulf of Mexico, S. attenuata has been observed only in deep waters beyond the shelf break, over the slope and deep gulf (Jefferson \& Schiro 1997, Baumgartner et al. 2001). The distribution in the SWA is similar to that in the Gulf of Mexico.

The southern range of the species in the SWA has been unclear. Most authors consider it to be the northern coast of Argentina (38 $\mathrm{S}$ ) (Brownell \& Praderi 1976, Praderi 1980, Perrin et al. 1987, Jefferson et al. 1993, Perrin \& Hohn 1994, Perrin 2001b). Rice (1998), on the other hand, proposes Rio Grande do Sul (30 to $34^{\circ} \mathrm{S}$ ), in southern Brazil, as the limit of the distribution.

Only 5 records of Stenella attenuata have been reported south of $25^{\circ} \mathrm{S}$ to date (Brownell \& Praderi 1976, Pinedo \& Castello 1980, Praderi 1980, Perrin et al. 1987, Cremer \& Simões-Lopes 1997, Petry \& Fonseca 2001). A review of these records showed that only an individual stranded in Uruguay (MNHNM 2694) (Praderi 1980, Ximenez \& Praderi 1992) was confirmed as $S$. attenuata. This specimen was erroneously cited as S. coeruleoalba in Bastida et al. (2001, p. 114, Record 8 in Table 1), but was later re-examined, and the skull measurements matched those of the pantropical spotted dolphin. The specimen MACN 23.46 reported by Brownell \& Praderi (1976) was obtained in Mar del Plata (Argentina) in 1926, but its origin is unknown. This specimen was also re-examined, and skull morphology and metrics suggested this was a spotted dolphin. However, these features have not allowed identification at the specific level. While this individual could indeed be a $S$. attenuata, more analyses (e.g. genetics) are needed to clarify species identity.

Among the 3 remaining records 2 corresponded to misidentifications. The specimen MCN 0026 stranded in Torres $\left(29^{\circ} 19^{\prime} \mathrm{S}, 049^{\circ} 42^{\prime} \mathrm{W}\right)$, Rio Grande do Sul, in February 1956, was originally reported as Stenella cf. plagiodon (Pinedo \& Castello 1980) and was subsequently identified as S. attenuata (Perrin et al. 1987). This individual was quoted as a pantropical spotted dolphin by several authors (e.g. Praderi 1991b, Pinedo et al. 1992, Ximenes \& Praderi 1992), until it was reexamined and re-identified as a common dolphin Delphinus sp., because of the presence of the pronounced palatal grooves typical of this genus (SimõesLopes \& Ximenez 1993).

The identity of the dolphin incidentally caught off São Paulo State on 28 August 1995 (Cremer \& SimõesLopes 1997) was unclear due to the relatively low quality picture available for examination and uncertainty regarding its morphological features. A more recent review of this individual's color patterns indicated it was in fact a specimen of Stenella frontalis.

Petry \& Fonseca (2001) reported that a pantropical spotted dolphin was stranded in October 1997 in southern Brazil (ca. $29^{\circ} \mathrm{S}$ ). No basis for species identification was provided by these authors, and no voucher material or pictures were obtained from this individual; therefore, its identity was considered to be unreliable.

Contemporary data indicate that Stenella attenuata is usually restricted to tropical waters in the SWA. The southernmost confirmed record in recent years comes from the coast of Rio de Janeiro State in southeastern Brazil $\left(22^{\circ} 42^{\prime} \mathrm{S}\right)$, where strandings of 3 animals were recently observed. Despite increasing research effort in relatively offshore waters (Zerbini et al. 2004a), no confirmed record of this species has been observed south of $23^{\circ} \mathrm{S}$. In addition, unlike other Stenella species, no incidental catches of pantropical spotted dolphins were observed in the driftnet fishery operat- 
ing in offshore waters off southern Brazil (Zerbini \& Kotas 1998). A review of museum collections did not reveal any recent record of $S$. attenuata in southern Brazil, Uruguay or Argentina either. Therefore, it is suggested here that the $23^{\circ} \mathrm{S}$ parallel corresponds to the southern limit of the distribution of $S$. attenuata in the SWA. However, considering that this species typically occurs in tropical waters and that the warm Brazil Current flows further south than the range proposed here, it is possible that the distribution of $S$. attenuata could extend further south to nearly 30 to $32^{\circ} \mathrm{S}$. This is consistent with a tropical distribution.

Data presented in this study suggest that the pantropical spotted dolphin seldom ventures into colder waters off the coast of Uruguay and Argentina. The specimen stranded in Uruguay $\left(\sim 34^{\circ} \mathrm{S}\right)$ (Ximenez \& Praderi 1992) possibly represents an extralimital record.

Spotted dolphins Stenella attenuata and S. frontalis seem to present a parapatric distribution along the eastern coast of South America. No records of S. attenuata in waters over the outer continental shelf and no records of $S$. frontalis beyond the slope were observed. However, a possible area of contact between the 2 species could be found off the southeastern Brazilian coast, more specifically on the coast of Rio de Janeiro, where records of $S$. attenuata in the shelf break are known (Salvatore Siciliano [Rio de Janeiro, 2005] pers. comm.).

\section{Clymene dolphin}

The Clymene dolphin is distributed in the SWA beyond the continental shelf, mainly over the slope or in deeper waters. This species also occurs in deep waters of the Gulf of Mexico and North Atlantic Ocean and, with few exceptions, is usually not found over the continental shelf (Davis et al. 1998). Fertl et al. (2003) reviewed habitat characteristics and distribution of the Clymene dolphin worldwide. They concluded that this species inhabits deeper waters and, in the SWA, seems to be more abundant off the northeastern Brazilian coast. The southern range of Stenella clymene is Rio Grande do Sul State (ca. 29 58' S), in southern Brazil (Fertl et al. 2003), but even in this area the species is considered uncommon. The only $S$. clymene recorded from this region was a female stranded in 2001, despite systematic beach surveys carried out over a period of $13 \mathrm{yr}$ in this region (Moreno et al. 2001).

\section{Spinner dolphin}

The spinner dolphin presents a pelagic habitat and a circumglobal tropical distribution (Jefferson et al.
1993, Perrin 2001c). In the SWA, Stenella longirostris was found both on the outer continental shelf and beyond the slope. There is a resident population near the Fernando de Noronha Archipelago $\left(03^{\circ} 51^{\prime} \mathrm{S}\right.$, $032^{\circ} 25^{\prime} \mathrm{W}$ ), where the dolphins congregate year round in the bay of dolphins for resting and mating, as they do in Hawaii (Silva et al. 2005). Jefferson et al. (1993) and Perrin (2002c) considered the south/southwestern coast of Brazil $\left(20\right.$ to $30^{\circ} \mathrm{S}$ ) the southern limit of this species in the SWA. This is consistent with the southernmost record of the spinner dolphin, an individual incidentally captured at $30^{\circ} 02^{\prime} \mathrm{S}, 046^{\circ} 17^{\prime} \mathrm{W}, 220 \mathrm{n}$ miles off the southern Brazilian coast (Zerbini \& Kotas 1998). The southern range of the species, as proposed by Jefferson et al. (1993) and Perrin (2002c), is further supported by the absence of records in Uruguay and Argentina.

\section{Striped dolphin}

The distribution of the striped dolphin extends across warm-temperate and tropical waters and is very well documented in the North Pacific, North Atlantic and in the Mediterranean Sea. Stenella coeruleoalba is the most abundant dolphin species in the Mediterranean (Archer \& Perrin 1999). Records at high latitudes of the North Atlantic and North Pacific suggest that this is likely the only Stenella species regularly found in temperate waters (Archer \& Perrin 1999). The striped dolphin is the least known species of Stenella in the SWA, where it seems not to be as abundant as in the Mediterranean Sea and in the Pacific Ocean. Only a few records were observed off the eastern coast of South America (Ott \& Danilewicz 1996, Lucena et al. 1998, Bastida et al. 2001, MaiaNogueira et al. 2001, Rosas et al. 2002). The records presented in this study were concentrated in colder waters in southern Brazil, Uruguay and Argentina, which might suggest a preference for more temperate environments in the SWA. However, strandings further north indicate that the species is also found in tropical waters.

The few sightings available were recorded in relatively nearshore and shallow waters $(<200 \mathrm{~m})$, but it is unlikely that the species distribution is restricted only to coastal waters in the SWA. Rosas et al. (2002) observed that the stomach contents of an individual stranded in southeastern Brazil contained remains of oceanic prey species, evidence that the striped dolphin also occurs in deeper waters.

Unlike for other Stenella species the relatively small number of records of $S$. coeruleoalba prevent a more detailed description of habitat preferences of the species. 


\section{CONCLUSIONS}

Cetacean habitat is often described as a function of the variables that influence the aggregation of their prey species (e.g. Davis et al. 1998, Cañadas et al. 2002). The sea-floor depth and relief, temperature and other oceanographic features are known to affect the occurrence of prey and therefore limit the dolphin distribution (Baumgartner et al. 2001, Davis et al. 2002). Studies conducted in the Gulf of Mexico and other ocean basins concluded that the best descriptor of cetacean distribution is the bottom depth (Reilly \& Fiedler 1993, Davis et al. 1998, Baumgartner et al. 2001). These results were obtained though statistical analysis of several oceanographic variables (e.g. seasurface temperature, salinity, depth, depth gradient, surface temperature, temperature at $100 \mathrm{~m}$, surface temperature variability, the depth of the $15^{\circ} \mathrm{C}$ isotherm, surface chlorophyll concentration and epipelagic zooplankton biomass).

In this study the distribution patterns of Stenella dolphins in the SWA were described in relation to oceanographic features (major water masses) and ocean topography (depth). S. attenuata, S. clymene and $S$. longirostris showed substantial overlap in their distribution and a clear preference for warm and deep waters. The latitudinal distribution of records and the ranges of SSTs in which these species were found, strongly suggest that they are associated with the Brazil Current. $S$. frontalis occurred in coastal waters under the influence of both tropical waters and also colder upwelling areas, where the SST can be slightly lower. None of these species were recorded further south than $34^{\circ} \mathrm{S}$, indicating that their southern range approximately corresponds to the limits of the northern boundary of the Subtropical Convergence (Boltovskoy 1981). The area under influence of the Subtropical Convergence has been proposed as a biogeographic transition zone between colder environments off Argentina and warmer regions in tropical Brazil (Castello \& Möller 1977). Other tropical cetaceans also appear to have their southern ranges near the Subtropical Convergence. For example, the roughtoothed dolphin Steno bredanensis is regularly found in the SWA, which does not occur further south than $32^{\circ} \mathrm{S}$ (Ott \& Danilewicz 1996). In contrast, colder water species, such as Commerson's dolphin Cephalorhynchus commersonii, the dusky dolphin Lagenorhynchus obscurus and Layard's beaked whale Mesoplodon layardii are found in temperate waters off the coast of Argentina, but very rarely occur in waters off southern Brazil (Pinedo et al. 2002), indicating that the Subtropical Convergence may also limit the northern distribution of temperate species in the SWA.

Seasonal variation in the boundaries of the Subtropical Convergence suggests that the distribution of the tropical species of Stenella may also vary. In the summer, when the Brazil Current reaches its maximum extension, these species likely expand their distribution to the southernmost portion of their ranges. In contrast, in the winter, they move north to avoid the colder waters of the Malvinas Current. This is consistent with the observed seasonal occurrence of $S$. frontalis in southern Brazil, which has been primarily observed in the warmer months (spring and summer).

This study makes clear the need for implementing or increasing survey effort in order to provide a more complete description of the distribution pattern of Stenella species. Notably, research should be focused along the northern coast of South America (west of Cabo de São Roque) and in deep offshore waters, off southern Brazil, Uruguay and Argentina. It is desirable that oceanographic data (e.g. SST, surface salinity, depth of $15^{\circ} \mathrm{C}$ isotherm) and other biological parameters (e.g. surface chlorophyll concentration, zooplankton biomass) be collected in order to investigate environmental features that influence the habitat and distribution of dolphins. Finally, systematic beach surveys should be implemented along the northern coast of South America.

Acknowledgements. We would especially like to thank the following people and institutions for collection and access to Stenella dolphins, laboratory support and other aid: M. BorgesMartins, P. H. Ott, P. Tavares, G. Caon and L. Oliveira, Grupo de Estudos de Mamíferos Aquáticos do Rio Grande do SulGEMARS; L. Barcelos, MORG/FURG; C. Pinedo, LMM/ FURG; E. Monteiro-Filho and F. Rosas, IPeC; B. Fragoso, MAQUA; A. Higa, MZUSP; S. Pacheco, FUNDAMAR; A. Vicente, F. Alvarenga and E. Zampirolli, CEEMAM; S. Siciliano, GEMM/ FICOCRUZ; L. Flamarion, MNRJ; L. W. Dórea-Reis, M. Socorro and R. Maia-Nogueira, CCPM and CRMA; E. Queiroz and A. Pereira, LABNEC/UFBA; R. Pinto, J. Vergara and C. Parente, CMA/IBAMA; A. Lucena and A. Langguth, UFPB; F. J. de Lima and P. Isabel, UFRN; C. Negrão, GECC/AQUASIS; R. Bastida and D. Rodrigues, UNMP; O. Vacaro, MACN; R. Pradreri, P. Laporta and J. Gonzáles, MNHN. Thanks to P. H. Ott, L. R. Oliveira, V. Ruoppolo, J. Marigo, C. P. Bertozzi and L. DallaRosa for access to unpublished data. J. Reinoso helped during the visit of MZUSP and PA collections. A. Andriolo, A. Lucena, G. R. VanBlaricom, J. M. Waite, J. da Rocha, J. Pizzorno, M. Bassoi, M. Cremer and S. Siciliano helped with data collection in the Minke Whale Project. Support for this project was provided by the Brazilian Environmental Agency (IBAMA), the Division of Hydrography and Navigation (DHN) of the Brazilian Navy, the Secretariat of the Inter-Ministy Commission for Marine Resources (SECIRM), the Scientifc Council for Science and Technology (CNPq) and the National Marine Mammal Laboratory (NMML/NMFS/NOAA). A. Higa, E. Secchi, L. de Sousa, L. Möller, L. Dalla-Rosa, M. Bassoi and R. Malta helped with data collection during the REVIZEE project. Many thanks to the colleagues and professors of the Ichthyology Laboratory MCT/PUCRS for their friendship and assistance. We are grateful to L. R. Malabarba for his helpful suggestions and comments to greatly improve early drafts of this paper and for his help with this study. This manuscript benefited from discussions about the dolphins' habitat and distribution with R. Praderi and R. L. de 
Moura. We also thank M. Borges-Martins, V. da Silva, R. Bastida, R. E. dos Reis, H. Smith, S. Siciliano for commenting on early drafts of this paper. This work was part of I.B.M.'s MSc studies at the Pontifícia Universidade Católica do Rio Grande do Sul in the Ichthyology Laboratory of Museu de Ciências e Tecnologia - MCT/PUCRS. I.B.M. received a scholarship from Capes and from CNPq (Grant 140660/2004-6 - 2004 to 2008), A.N.Z. and A.F.A received scholarships from CNPq (Grants 200.285/98-0 and 140853/02-2), and P.C.S.L. received a research grant from CNPq (Grant 302749/2002-0). Additional funding was provided by the Society for Marine Mammalogy under the Grants-in-Aid of Research, The Humane Society of the United States - HSUS, and the Cetacean Society International - CSI. The Fundação O Boticário de Proteção à Natureza, Fundo Nacional do Meio Ambiente-FNMA/MMA and The Yaqu Pacha Foundation provided funds to the Grupo de Estudos de Mamíferos Aquáticos do Rio Grande do Sul that contributed to this project. The manuscript was reviewed and substantially improved by comments from W. F. Perrin and 3 anonymous reviewers. This paper is GEMARS Contribution Number 15.

\section{LITERATURE CITED}

Andriolo A, Martins CCA, Engel MH, Pizzorno JL, Más-Rosa S, Morete ME, Kinas PG (2003) Second year of aerial survey of humpback whale (Megaptera novaeangliae) in the Brazilian breeding ground, 2002. Preliminary analyses. $\mathrm{SC} / 55 / \mathrm{SH} 1$. Scientific Committee-International Whaling Commission, Berlin

Archer II FI, Perrin WF (1999) Stenella coeruleoalba. Mamm Species 603:1-9

Bastida R, Rodrigues D, Desojo J, Rivero L (2001) La presencia del delfín listado, Stenella coeruleoalba, en el mar Argentino. J Neotrop Mamm 8:111-127

Baumgartner MF, Mullin KD, May LN, Leming TD (2001) Cetacean habitats in the northern Gulf of Mexico. Fish Bull (Wash DC) 99:219-239

Boltovskoy E (1981) Massas de água en Atlántico Sudoccindental. In: Boltovskoy D (ed) Atlas del zooplancton del Atlántico sudoccindental y metodos de trabajo con el zooplancton marino. Publicación Especial del INIDEP, Mar del Plata, p 227-237

Borzone CA, Pezzuto PR, Marone E (1999) Oceanographic characteristics of a multi-specific fishing ground of the Central South Brazil Bight. PSZN I: Mar Ecol 20:131-146

Brownell Jr RL, Praderi R (1976) Records of the delphinid genus Stenella in western south Atlantic waters. Sci Rep Whales Res Inst 28:129-135

Cañadas A, Sagarminaga R, García-Tiscar S (2002) Cetacean distribution related with depth and slope in the Mediterranean waters off southern Spain. Deep-Sea Res 49: 2053-2073

Castello JP, Möller OO (1977) On the oceanographic conditions in the Rio Grande do Sul State. Atlántica 2:25-110

Cremer JM, Simões-Lopes PC (1997) Accidental capture of the pantropical spotted dolphin Stenella attenuata (Gray, 1846) (Delphinidae) in the southwestern South Atlantic Ocean. Biocièncias 5:231-233

Danilewicz D (2003) Reproduction of female franciscana (Pontoporia blainvillei) in Rio Grande do Sul, southern Brazil. Latin Am J Aquat Mamm 2:67-78

Davis RW, Fargion GS, May N, Lemig TD, Baumgartner M, Evans WE, Hansen LJ, Mullin K (1998) Physical habitat of the cetaceans along the continental slope in the north- central and western Gulf of Mexico. Mar Mamm Sci 14: 490-507

Davis RW, Ortiga-Ortiz JG, Ribic CA, Evans WE and 6 others (2002) Cetacean habitat in the northern oceanic Gulf of Mexico. Deep-Sea Res 49:121-142

Di Beneditto APM (2003) Interactions between gillnet fisheries and small cetaceans in northern Rio de Janeiro, Brazil: 2001-2002. Latin Am J Aquat Mamm 2:79-86

Fertl D, Jefferson TA, Moreno IB, Zerbini AN, Mullin KD (2003) Distribution of the Clymene dolphin Stenella clymene. Mamm Rev 33(3):253-271

Floeter SF, Guimarães RZP, Rocha LA, Ferreira CAL, Rangel CR, Gasparini JL (2001) Geographic variation in reef-fish assemblages along the Brazilian coast. Global Ecol Biogeogr 10:423-431

Garzoli SL (1993) Geostrophic velocity and transport variability in the Brazil-Malvinas Confluence. Deep-Sea Res 40: 1379-1403

Jefferson TA, Schiro AJ (1997) Distribution of cetaceans in the offshore Gulf of Mexico. Mamm Rev 27:27-50

Jefferson TA, Leatherwood S, Webber MA (1993) Marine mammals of the world. FAO Species Identification Guide. UNEP-FAO, Rome

LeDuc RG, Perrin WF, Dizon AE (1999) Phylogenetic relationships among the delphinid cetaceans based on full cytocrome $B$ sequences. Mar Mamm Sci 15:619-648

Legeckis R, Gordon AL (1982) Satellite observations of the Brazil and Falkland currents - 1975 to 1976 and 1978. Deep-Sea Res 29:375-401

Lucena A, Paludo D, Langguth A (1998) New records of Odontoceti (Cetacea) from the coast of Paraíba, Brazil. Rev Nordestina Biol 12:19-27

Maia-Nogueira R, Farias TS, Cunha IF, Dórea-Reis LW, Braga FL (2001) Primeiro registro de Stenella coeruleoalba Meyen, 1833 (Cetacea, Delphinidae) no litoral do Estado da Bahia, incluindo uma revisão da espécie em águas brasileiras. Bioikos 15:45-49

Moreno IB (2002) Padrão de distribuição dos golfinhos do gênero Stenella (Delphinidae: Cetacea) no oceano Atlântico sul-ocidental e morfometria craniana dos GolfinhosPintados (Stenella frontalis e $S$. attenuata). MSc thesis, Pontifícia Universidade Católica do Rio Grande do Sul, Rio Grande do Sul

Moreno IB, Danilewicz D, Ott PH, Martins MB, Oliveira LR, Caon C (2001) 10 anos de praia: uma revisão dos registros de mamíferos marinhos no litoral norte do Rio Grande do Sul, Brasil, entre 1991 e 2001. In: Freitas TRO (ed) Resumos $\mathrm{I}^{\circ}$ Congresso Brasileiro de Mastozoologia. Sociedade Brasileira de Mastozoologia, Porto Alegre, p 44

Ott PH, Danilewicz D (1996) Southward range extension of Steno bredanensis in the Southwest Atlantic and new records of Stenella coeruleoalba for Brazilian waters. Aquat Mamm 22:185-189

Paiva MP (1997) Recursos pesqueiros estuarinos e marinhos do Brasil. Universidade Federal do Ceará Edições, Fortaleza

Perrin WF (1975) Variation of spotted and spinner porpoise (genus Stenella) in the eastern tropical Pacific and Hawaii. Bull Scripps Inst Oceanogr Univ Calif 21:1-206

Perrin WF (2001a) Stenella frontalis. Mamm Species 702:1-6 Perrin WF (2001b) Stenella attenuata. Mamm Species 683:1-8 Perrin WF (2001c) Stenella longirostris. Mamm Species 599: $1-8$

Perrin WF, Hohn AA (1994) Pantropical spotted dolphin Stenella attenuata. In: Ridgway SH, Harrison R (eds) Handbook of marine mammals, Vol 5: the first book of dolphins. Academic Press, London, p 71-98 
Perrin WF, Mitchell ED, Mead JG, Caldwell DK, van Bree PJH (1981) Stenella clymene, a rediscovered tropical dolphin of the Atlantic. J Mamm 62:583-598

Perrin WF, Mitchell ED, Mead JG, Caldwell DK, Caldwell MC, van Bree PJH, Dawbin WH (1987) Revision of the spotted dolphins, Stenella spp. Mar Mamm Sci 3:99-170

Peterson RG, Stramma L (1990) Upper-level circulation in the South Atlantic Ocean. Prog Oceanogr 26:1-73

Petry MV, Fonseca VSS (2001) Mamíferos marinhos encontrados mortos no litoral do Rio Grande do Sul de 1997 a 1998. Acta Biol Leopold 23:225-235

Pinedo MC, Castello HP (1980) Primeiros registros dos golfinhos, Stenella coeruleoalba, Stenella cf plagiodon e Steno bredanensis para o sul do Brasil, com notas osteológicas. Bol Inst Ocean 29:313-317

Pinedo MC, Marmontel M, Rosas FCW (1992) Cetáceos e Pinípedes do Brasil. Uma revisão dos registros e guia para a identificação das espécies. UNEP/FUA, Manaus

Pinedo MC, Barreto AS, Lammardo MP, Andrade ALV, Geracitano L (2002) Northernmost records of the spectacled porpoise, Layard's beaked whale, Commerson's dolphin, and Peale's dolphin in the southwestern Atlantic Ocean. Aquat Mamm 28:32-37

Praderi R (1980) Adiciones a la lista sitemática de cetáceos de Uruguay. Res J Cienc Nat 1:136-137

Praderi R (1991a) Delfin Pintado, Stenella frontalis (Cuvier, 1829). In: Capozzo HL, Junin $M$ (eds) Estado de Conservación de los mamíferos marinos del Atlántico Sudoccidental. No. 138. Informes y estudios del Programa de Mares Regionales del PNMA, Nairobi, p 58-60

Praderi R (1991b) Delphin Moteado, Stenella attenuata (Gray, 1846). In: Capozzo HL, Junin M (eds) Estado de Conservación de los mamíferos marinos del Atlántico Sudoccidental. No. 138. Informes y estudios del Programa de Mares Regionales del PNMA, Nairobi, p 61-62

Reilly SB, Fiedler PC (1993) Interannual variability of dolphin habitats in the eastern tropical Pacific. I. Research vessel surveys, 1986-1990. Fish Bull (Wash DC) 92:434-450

Rice DW (1998) Marine mammals of the world: systematics and distribution. Special Publication Number 4. Society for Marine Mammalogy, Lawrence, KS

Romero A, Agudo I, Green SM, Notabartolodi Sciara G (2001) Cetaceans of Venezuela: their distribution and conservation status. NOAA Tech Rep NMFS 151:1-60

Rosas FCW, Monteiro-Filho ELA, Marigo J, Santos RA, Andrade ALV, Rautenberg M, Oliveira MR, Bordignon MO (2002) The striped dolphin, Stenella coeruleoalba

Editorial responsibility: Otto Kinne (Editor-in-Chief), Oldendorf/Luhe, Germany
(Cetacea: Delphinidae), on the coast of São Paulo State, southeastern Brazil. Aquat Mamm 28:60-66

Scott MD, Perryman WL, Clark WG (1985) The use of aerial photographs for estimating school sizes of cetaceans. Inter-American Trop Tuna Comm Bull 18(5):383-419

Secchi ER, Siciliano S (1995) Comments on the southern range of the spinner dolphin (Stenella longirostris) in the western South Atlantic. Aquat Mamm 21:105-108

Seeliger U, Oderbrecht C, Castello JP (1997) Subtropical convergence environments - the coast and sea in the southwestern Atlantic. Springer-Verlag, Berlin

Silva Jr JM, Silva FJL, Sazima I (2005) Rest, nurture, sex, release, and play: diurnal underwater behaviour of the spinner dolphin at Fernando de Noronha Archipelago, SW Atlantic. J Ichthyol Aquat Biol 9:161-176

Simões-Lopes PC, Ximenez A (1993) Annotated list of the cetaceans of Santa Catarina coastal waters, southern Brazil. Biotemas 6:67-92

Simões-Lopes PC, Praderi R, Paula GS (1994) The Clymene dolphin, Stenella clymene (Gray, 1846), in the southwestern South Atlantic Ocean. Mar Mamm Sci 10:213-217

Valentini H, Cardoso RD (1991) Análise da pesca de sardinhaverdadeira, Sardinella brasiliensis, na costa Sudeste-Sul do Brasil. Atlántica 13:45-54

Wade PR, Gerrodette T (1993) Estimates of cetacean abundance and distribution in the eastern tropical Pacific. Rep Int Whaling Comm 43:477-493

Würsig B, Jefferson TA, Schmidly DJ (2000) The marine mammals of the Gulf of México. Texas A\&M University Press, College Station, TX

Ximenez A, Praderi R (1992) Nuevos aportes sobre el conocimiento de los delfines del genero Stenella para el Atlantico Sudoccidental. In: Oporto JA, Brieva LM, Praderi R (eds) Anales 3ra Reunión de Trabajo de Especialistas en Mamíferos Acuáticos de América del Sur. CIMMA, Montevideo, p 72-79

Zerbini AN, Kotas JE (1998) A note on cetacean bycatch in pelagic driftnets of southern Brazil. Rep Int Whaling Comm 48:519-524

Zerbini AN, Secchi ER, Bassoi M, Dalla-Rosa L and 5 others (2004a) Distribuição e abundância relativa de cetáceos na Zona Econômica Exclusiva na Região Sudeste-Sul do Brasil. Série Documentos Revizee-Score Sul. Instituto Oceanográfico, Universidade de São Paulo

Zerbini AN, Andriolo A, da Rocha JM, Simões-Lopes PC and 5 others $(2004 \mathrm{~b})$ Winter distribution and abundance of humpback whales (Megaptera novaeangliae) off northeastern Brazil. J Cetacean Res Manage 6(1):101-107

Submitted: August 25, 2004; Accepted: May 26, 2005

Proofs received from author(s): August 23, 2005 